\author{
G.M. Zhangozhina*, D.V. Czernykh \\ Altai State University, Barnaul, Russia \\ *Corresponding author: zhan_bastal@mail.ru
}

\title{
Long-term meteorological trends of atmospheric precipitation in the Nura river basin (the Central Kazakhstan)
}

\begin{abstract}
For living organisms, the main indicators are the average values are meteorological and hydrological parameters that determine the coverage of the survival of species. Currently, all research on the trend in the landscape of river basins should begin with an analysis of climate change, which is currently undergoing rapid dynamic changes. The purpose of the study is to analyze the long meteorological trends of atmospheric humidity of the Nura River Valley. In the presented study, we analyzed the daily data of two weather stations of the Central Kazakhstan for the period from 1939 to 2019 within. The territory of the Nura river basin belongs to areas of pronounced insufficient moisture. A distinctive feature of the river is that the bulk of the annual flow takes place in a short period of spring flood (early April to mid-May, 4-5 months). Within the Nura river basin, reliable trends of significant changes in annual, semi-annual and seasonal amounts of atmospheric precipitation have been revealed. All identified trends have positive indicators. The results can be used for agricultural planning in the context of climate change in the Central Kazakhstan.
\end{abstract}

Keywords: Nura river, basin, the Central Kazakhstan, meteorology, long-term changes, precipitation.

\section{Introduction}

A necessary prerequisite for studying climate change and its effects is the availability of meteorological data for the period of observation and information on their expected changes in the future. The purpose of the article is to describe the available in the free access of data arrays of modern meteorological observations in Russia, as well as a review of the results of calculations on hydrodynamic models climate, on the basis of which projections are built for the future [1-4]. The article considers two most important weather elements - ground-level air temperature and atmospheric precipitation.

The modern ecological and geographical studies can cover any territory defined by both political and administrative or natural (landscape) borders, boundaries of river basins $[5,6]$. For determination of the climatic comfort in the river basin, it is necessary to evaluate the main long-term directions of the most important meteorological and hydrological parameters. Long-term changes in air temperatures determine changes in evaporation from the day surface, and, therefore, can lead to a decreasing or increasing in humidification in the regions [7-11].

The aim of our study was to analyze the long-term meteorological trends of atmospheric precipitation in the Nura river basin.

\section{Materials and methods}

The basin of the Nura river is the main basin of the Karaganda region [12]. The beginning of the river is three rills, which located on the north of the Konyrtobe Mountains at an altitude of about $1200 \mathrm{~m}$. Nura flows into the drainless lake Teniz at an elevation $304 \mathrm{~m}$. The total length of the river is $978 \mathrm{~km}$; the catchment area is 58.1 thousand $\mathrm{km}^{2}$. The average perennial flow is 619 million $\mathrm{m}^{3}$. In the river basin there are 3 main weather stations (Karaganda, Czernigovka and Besoba), 2 of which are active.

The daily data of two weather stations of the Central Kazakhstan is statistically analyzed for the period from 1939 to 2019; for Besoba weather station — only from 1992 to 2009.

The amount of atmospheric precipitation for different periods (month, season, half-year, year) was calculated as the sum of their daily amount for the necessary time periods. Using averaged data from the average daily air temperature, the average atmospheric air temperatures for the month, year, season and half year were calculated. On the basis of daily data, absolute maximum and minimum air temperatures were also detected for different periods of the year $[1,12]$. 
For the obtained multi-year data lines, graphs of their multi-year movements are plotted and correlation coefficients between the actual data and their linear trends are calculated. In this case, only those correlation coefficients were used, the significance of which ranged from $90 \%$ to $99.9 \%$ [12]. The relative coefficient of change, expressed in percent, was calculated, which is calculated as the ratio of the module of change of trend values of temperature (or precipitation) over a long-term period to the module of amplitude of fluctuation of actual (measured) values of this parameter in a long-term aspect:

$$
K_{\text {chang }}=\left|\begin{array}{cc}
F\left(t_{n}\right)- & F\left(t_{1}\right) \\
t_{\max } & t_{\min }
\end{array}\right| 100 \%
$$

Where $F\left(t_{n}\right)$ and $F\left(t_{1}\right)$ are initial and final linear trend values of the estimated meteorological characteristic (temperature or precipitation); $t_{\max }$ and $t_{\min }$ are maximum and minimum actual (measured) values of this parameter (temperature of average, maximum, minimum or precipitation) for a multi-year period.

\section{Results and discussion}

The values of significant correlation coefficients for the amounts of atmospheric precipitation ranged from +0.09 (for the warm half-year in Besoba) to +0.38 (for the cold period in Karaganda); and the values of the changes in atmospheric precipitation themselves range from 122 to $547 \mathrm{~mm}$.

Significant reliable trends in the multi-year placement of annual, semi-annual and seasonal amounts of atmospheric precipitation were revealed for almost two analyzed stations of the Nura river basin; all of them are significant and positive (no negative trends were revealed). In both stations their reliable trends fluctuate within $r=+0.31$ and $r=+0.38$ (Table 1 ).

$\mathrm{Table} 1$

\section{Analysis of trends of long-term changes in annual precipitation values in the region of the Central Kazakhstan (1936-2019)}

\begin{tabular}{|c|c|c|c|c|c|c|c|c|c|}
\hline \multirow{2}{*}{ Station } & \multicolumn{2}{|c|}{ Periods } & \multicolumn{7}{|c|}{ Precipitation } \\
\hline & Seasons & Months & Years & Trends & $r^{1}$ & $\alpha^{2}$ & $\mathrm{Sr}^{3}$ & $\Delta^{4}$ & OKI, $\% 5$ \\
\hline \multirow{7}{*}{ Karaganda } & year & $1-12$ & 83 & + & 0,21 & 0,22 & 122 & 142 & 33,5 \\
\hline & warm half-year & $4-9$ & 83 & + & 0,02 & 0,22 & 364 & 47 & 12,9 \\
\hline & cold half-year & $10-3$ & 83 & + & 0,38 & 0,22 & 210 & 108 & 51,4 \\
\hline & spring & $3-5$ & 83 & + & 0,13 & 0,22 & 152 & 40 & 26,6 \\
\hline & summer & $6-8$ & 83 & + & 0,11 & 0,22 & 219 & 16 & 7,3 \\
\hline & autumn & $9-11$ & 83 & + & 0,18 & 0,22 & 123 & 23 & 18,6 \\
\hline & winter & $12-2$ & 83 & + & 0,30 & 0,22 & 126 & 52 & 41,2 \\
\hline \multirow{7}{*}{ Besoba } & year & $1-12$ & 61 & + & 0,07 & 0,25 & 230 & 2 & 20 \\
\hline & warm half-year & $4-9$ & 61 & + & 0,04 & 0,25 & 28,7 & 1 & 1,8 \\
\hline & cold half-year & $10-3$ & 61 & + & 0,31 & 0,25 & 11,7 & 3 & 8,5 \\
\hline & spring & $3-5$ & 61 & + & 0,18 & 0,25 & 21,3 & 10 & 7,6 \\
\hline & summer & $6-8$ & 61 & + & 0,16 & 0,25 & 33,9 & 4,6 & 3,1 \\
\hline & autumn & $9-11$ & 61 & + & 0,08 & 0,25 & 17,1 & 5,4 & 7,5 \\
\hline & winter & $12-2$ & 61 & + & 0,13 & 0,25 & 8,5 & 3 & 9,6 \\
\hline
\end{tabular}

Note: 1) $r^{1}$-correlation coefficient of linear trend with curves of actual long-term precipitation values; 2) $\alpha^{2}$ - significance of correlation coefficients; 3) $\mathrm{Sr}^{3}$ - average quantity of a total atmospheric precipitation for the long-term period according to actual data; 4) $\Delta^{4}$ - module of change of actual value for the period under review, calculated on the basis of trend; 5) OKI, \% ${ }^{5}$ is the percentage of change in actual average precipitation values calculated as the ratio of the module to the module of the average parameter value (in \%)

For the weather station (Karaganda) a low $(r=+0.18$; Table 1) reliable seasonal trend in autumn (9-11 months) and also the correlation coefficient was revealed in the weather station Besoba, where a reliable seasonal trend falls in spring (3-5 months) (Fig. 1-3).

For the weather stations under consideration, with trends of long-term changes in annual and semiannual amounts of atmospheric precipitation, significant trends are also characteristic for various seasons of the year. The main dynamics in seasonal redistribution of precipitation is their unconditional increase in winter $(1-2,12)$ and partly in autumn $(9-11)$ (Fig. 4). 


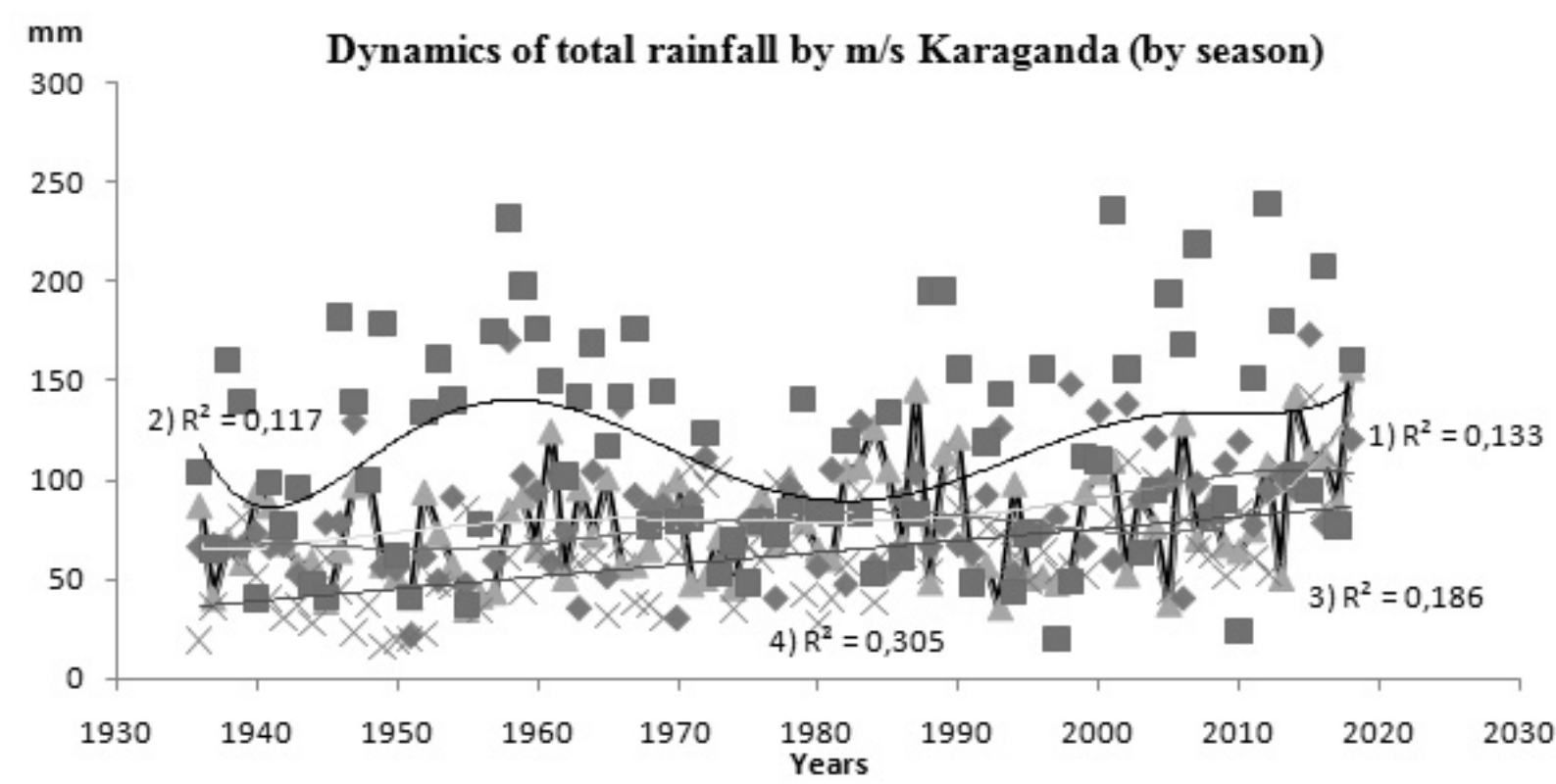

1 - precipitation of the spring period (3-5 months); 2 - precipitation of the summer period (6-8 months); 3 and $4-$ precipitation of the autumn-winter period (9-11 and 1-2, 12 months)

Figure 1. Positive reliable trends in the long-term dynamics of atmospheric precipitation by season (Karaganda weather station)

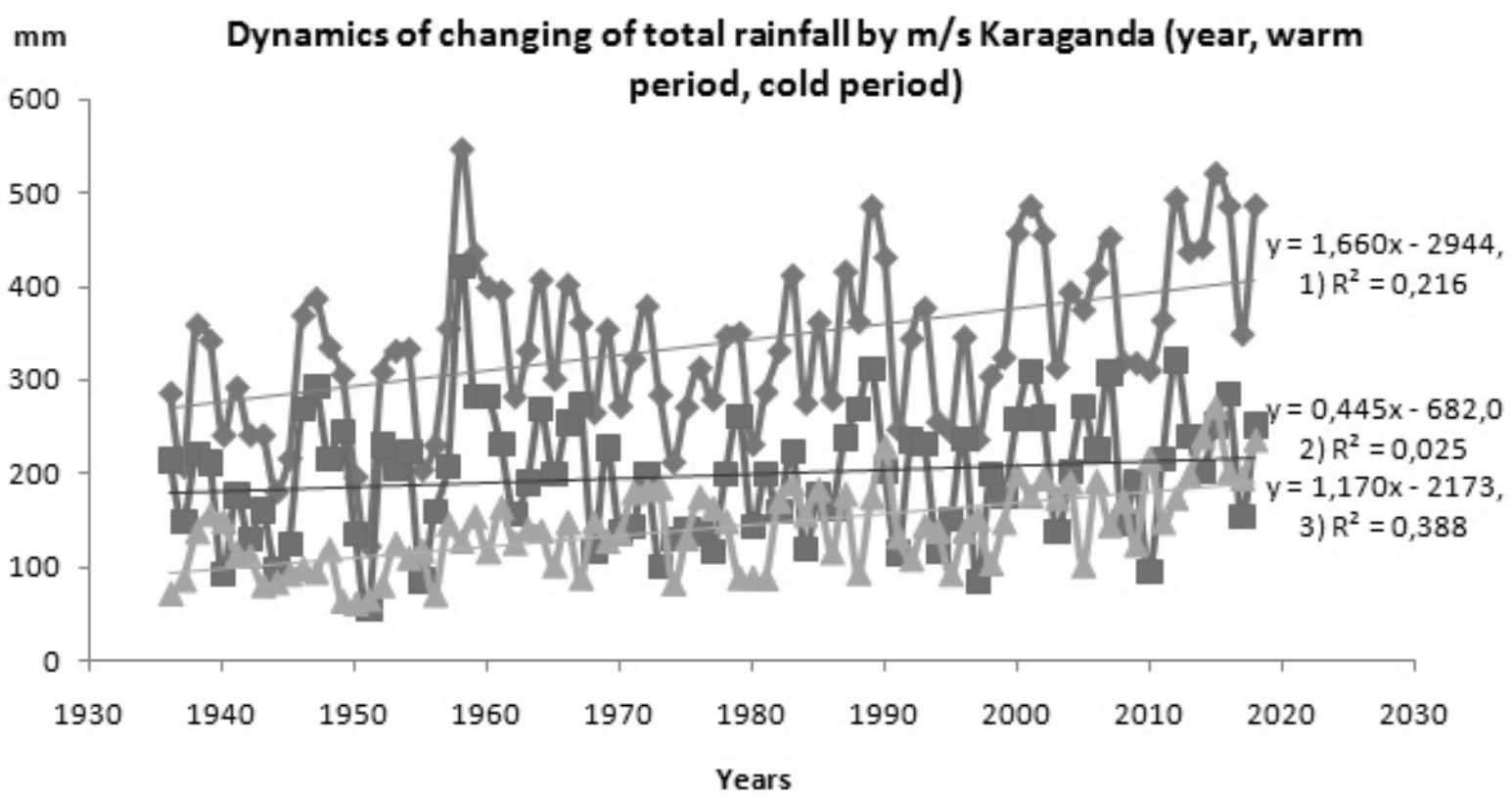

1 - total annual rainfall; 2 - precipitation of the cold half-year (1-3, 10-12 months); 3 - precipitation of the warm half-year (4-9 months)

Figure 2. Positive reliable trends in the long-term dynamics of atmospheric precipitation for the year of the Karaganda station 


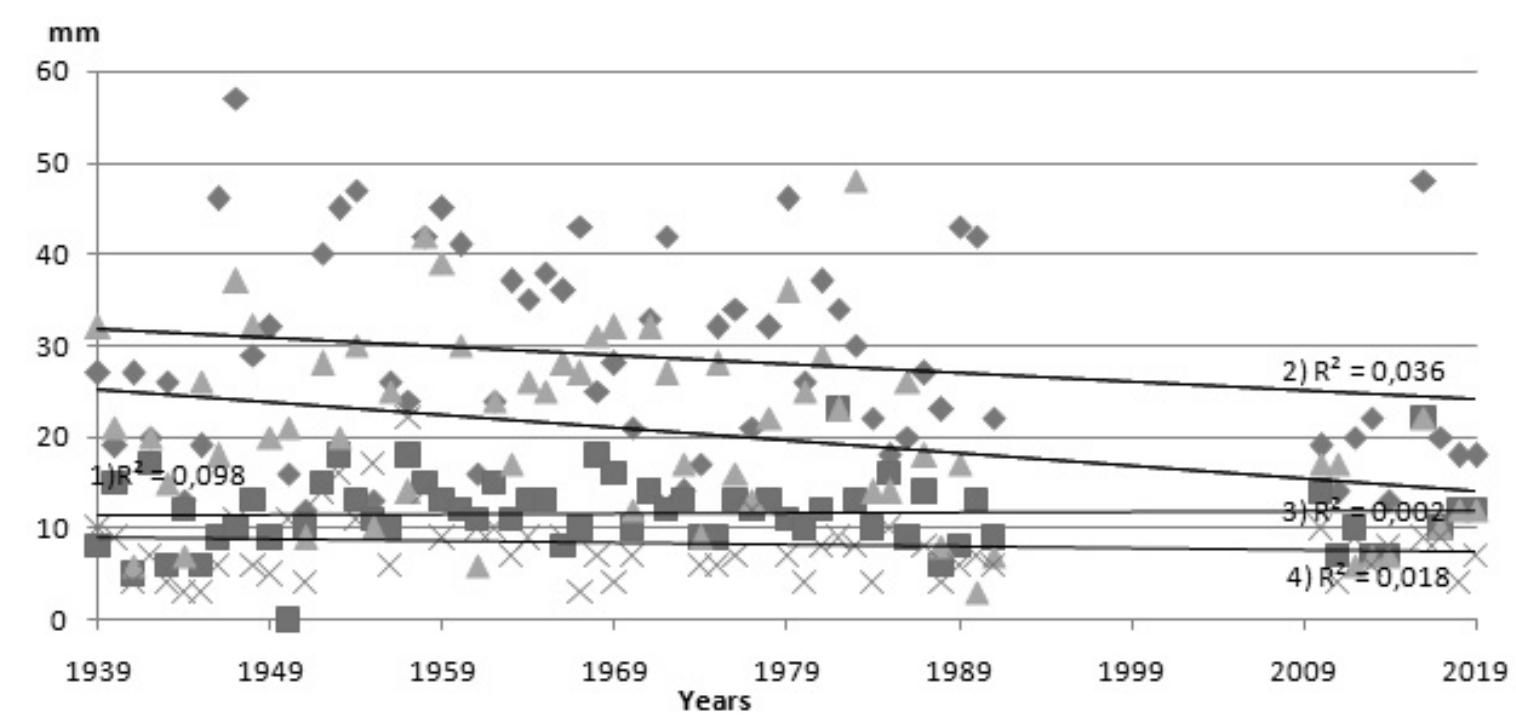

1 - precipitation of the spring period (3-5 months); 2 - precipitation of the warm half-year (4-9 months); 3 - precipitation of the cold half-year (10-3 months); 4 - precipitation of the winter period (1-2, 12 months)

Figure 3. Positive reliable trends in the long-term dynamics of atmospheric precipitation by season (Besoba weather station)

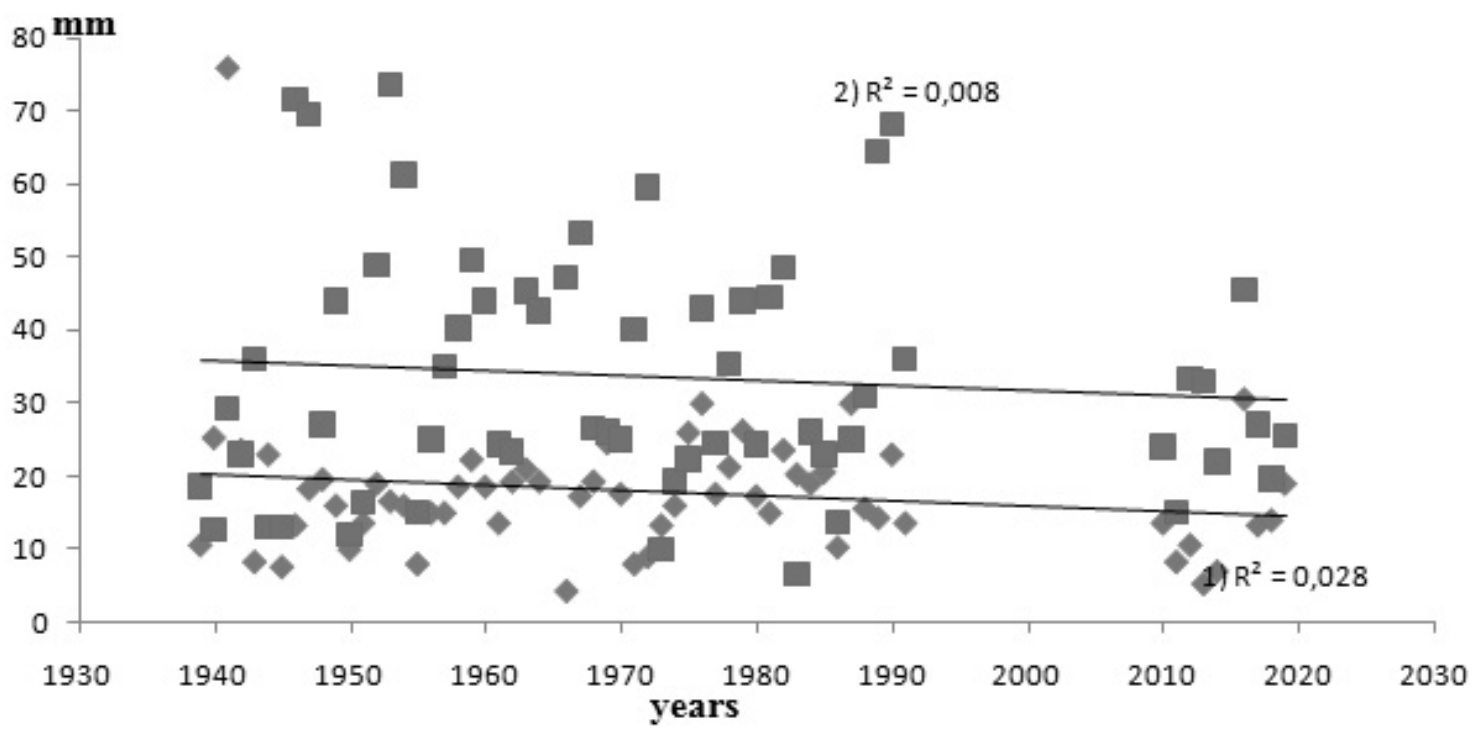

1 - summer precipitation (6-8 months); 2 - autumn precipitation (9-11 months)

Figure 4. Positive reliable trends in the long-term dynamics of atmospheric precipitation by season (Besoba weather station)

Thus, the trend of a noticeable significant increase in atmospheric precipitation over the year for the regions of most of the Nura River basin of epy Central Kazakhstan was revealed. For most of the Nura River basin, a significant increase in annual precipitation occurs mainly due to the cold half of the year. For a smaller part of the weather station of the Nura River basin located east (Besoba), a significant increase in the annual amount of atmospheric precipitation occurs due to the autumn-summer period.

For the river basins of the steppe zone of Russia and Kazakhstan, over the past century, there has been a tendency to redistribute atmospheric precipitation towards their increase in the cold half-year, which contributes to a change in soil and soil conditions in floodplains and watersheds [13, 14]. 


\title{
Conclusions
}

Based on stock data and our own analysis of multi-year materials, the following conclusions can be drawn. The territory of the Nura river basin belongs to areas of pronounced insufficient moisture. A distinctive feature of the river is that the bulk of the annual flow takes place in a short period of spring flood (early April to mid-May, 4-5 months).

For both weather stations of the Central Kazakhstan within the Nura river basin, reliable trends of significant changes in annual, semi-annual and seasonal amounts of atmospheric precipitation were revealed; all revealed trends have positive indicators.

The article has been prepared as a part of complex survey of river valleys of the Karaganda region (the Central Kazakhstan) carried out within the framework of cooperation between E.A. Buketov Karaganda University and Altai State University (Barnaul).

\section{References}

1 Кокорев В.А. О метеорологических данных для изучения современных и будущих изменений климата на территории России / В.А. Кокорев, А.Б. Шерстюков // Арктика, естественные науки. — 2015. — № 2. - С. 5-23.

2 Анисимов О.А. Об оценках изменений климата регионов России в XX и начале XXI веков по данным наблюдений / О.А. Анисимов, Е.Л. Жильцова // Метеорология и гидрология. — 2012. — № 6. — С. 95-107.

3 Груза Г.В. О неопределенности некоторых сценарных климатических прогнозов температуры воздуха и осадков на территории России / Г.В. Груза, Э.Я. Ранькова, Л.Н. Аристова и др. // Метеорология и гидрология. — 2006. — № 10. — С. 523.

4 Жильцова Е.Л. О точности воспроизведения температуры и осадков на территории России глобальными климатическими архивами / Е.Л. Жильцова, О.А. Анисимов // Метеорология и гидрология. — 2009. — № 10. — С. 79-90.

5 Исаченко А.Г. Введение в экологическую географию: учеб. пос. / А.Г. Исаченко. - СПб.: Изд-во СПб. ун-та, 2003. $-192 \mathrm{c}$.

6 Jabbari A. Precipitation forecast contribution assessment in the coupled meteo-hydrological models / A. Jabbari, J.-M. So, D.-H. Bae // Atmosphere. — 2020. — Vol. 11, Iss. 1. — P. 34. https://doi.org/10.3390/atmos11010034

7 Кокорев В.А. Построение оптимизированной ансамблевой климатической проекции для оценки последствий изменений климата на территории России / В.А. Кокорев, О.А. Анисимов // Проблемы экологического моделирования и мониторинга экосистем. - 2013. - Т. 25. - С. 131-153.

8 Harris I. Updated high-resolution grids of monthly climatic observations - the CRU TS3.10 Dataset / I. Harris, P.D. Jones, T.J. Osborn // International Journal of Climatology. — 2014. — Vol. 34. — No. 3. — P. 623-642.

9 Кузьмина Ж.В. Климатические изменения в бассейне Нижней Волги и их влияние на состояние экосистем / Ж.В. Кузьмина, С.Е. Трешкин // Аридные экосистемы. — 2004. — Т. 20, № 3(60). — С. 14-32.

10 Kouzmina J.V. The impact of natural and human-induced changes in the river flow and the climate on flood plain ecosystems in the middle Elbe river basin / J.V. Kouzmina // Ecological Engineering and Environment protection. — 2004. — No. 2. — P. 5-15.

11 Акпамбетова К.М. Географические факторы размещения речных долин на территории Центрального Казахстана / К.М. Акпамбетова, Г.Б. Абиева // Евразийский союз ученых. - 2019. — № 4(61). - С. 26-31.

12 Дмитриев Е.А. Математическая статистика в почвоведении / Е.А. Дмитриев. - М.: МГУ, 1995. — 320 с.

13 Saraf V.R. Assessment of climate change for precipitation and temperature using statistical doqnscaling methods in upper Godavari river basin, India / V.R. Saraf, D.G. Regulwar // Journal of Water Resource and Protection. — 2016. - Vol. 8. — P. 3445. https://doi.org/10.4236jwrp.2016.81004

14 Ghebrezgabher M.G. Long-term trend of climate change and drought assessment in the horn of Africa / M.G. Ghebrezgabher // Advances in Meteorology. — 2016. — Article ID 8057641 https://doi.org/10.1155/2016/8057641

\section{Г.М. Жангожина, Д.В. Черных}

\section{Нұра өзені бассейніндегі атмосфералық жауын-шашынның ұзақ мерзімді метеорологиялық үрдістері (Орталық Қазақстан)}

\begin{abstract}
Tiрi организмдер үшін негізгі көрсеткіштер түрлердің тірі қалуын қамтуды айқындайтын метеорологиялық және гидрологиялық параметрлердің орташа мәндері болып табылады. Қазіргі уақытта өзендер бассейндерінің ландшафтындағы үрдістерді барлық зерттеу қазіргі уақытта жылдам серпінді өзгерістерге ұшырайтын климаттың өзгеруін талдаудан басталуы тиіс. Зерттеудің мақсаты Нұра өзені аңғары атмосферасының ылғалдылығының ұзақ метеорологиялық үрдістерін талдау. Ұсынылған зерттеуде авторлар Орталық Қазақстанның 1939-2019 жылдар аралығындағы екі метеостанциясының күн сайынғы мәліметтеріне талдау жасаған. Нұра өзені бассейнінің аумағы ылғалдылығы жеткіліксіз учаскелерге жатады. Өзеннің ерекшелігі — жылдық ағынның негізгі бөлігі
\end{abstract}


көктемгі су тасқынының қысқа кезеңінде (сәуірдің басы - мамыр айының ортасы, 4-5 ай) өтеді. Нұра өзені бассейнінде атмосфералық жауын-шашынның жылдық, жартыжылдық және маусымдық көлемдерінің айтарлықтай өзгерістерінің шынайы үрдістері анықталды. Барлық анықталған үрдістер оң көрсеткіштерге ие. Алынған нәтижелер Орталық Қазақстандағы климаттың өзгеруі тұрғысында ауыл шаруашылығын жоспарлау үшін пайдаланылуы мүмкін.

Кілт сөздер: Нұра өзені, бассейн, Орталық Қазақстан, метеорология, ұзақ мерзімді өзгерістер, ылғалдылық.

\title{
Г.М. Жангожина, Д.В. Черных
}

\section{Долгосрочные метеорологические тенденции атмосферных осадков в бассейне реки Нуры (Центральный Казахстан)}

\begin{abstract}
Для живых организмов основными показателями являются средние значения метеорологических и гидрологических параметров, определяющих охват выживания видов. В настоящее время все исследования тенденций в ландшафте бассейнов рек должны начинаться с анализа изменения климата, которое в настоящее время претерпевает быстрые динамические изменения. Цель исследования - анализ длительных метеорологических тенденций влажности атмосферы долины реки Нуры. В представленном исследовании авторы проанализировали ежедневные данные двух метеостанций Центрального Казахстана за период с 1939 по 2019 гг. Территория бассейна реки Нуры относится к участкам с выраженной недостаточной влажностью. Отличительной особенностью реки является то, что основная часть годового стока происходит в короткий период весеннего половодья (начало апреля - середина мая, 4-5 месяцев). В бассейне реки Нуры выявлены достоверные тенденции существенных изменений годовых, полугодовых и сезонных объемов атмосферных осадков. Все выявленные тенденции имеют положительные показатели. Полученные результаты могут быть использованы для планирования сельского хозяйства в контексте изменения климата в Центральном Казахстане.
\end{abstract}

Ключевые слова: река Нура, бассейн, Центральный Казахстан, метеорология, долгосрочные изменения, влажность.

\section{References}

1 Kokorev, V.A., \& Sherstyukov, A.B. (2015). O meteorolohicheskikh dannykh dlia izucheniia sovremennykh i budushchikh izmenenii klimata na territorii Rossii [About meteorological data for study modern and future climate change at the territory of Tussia]. Arktika, estestvennye nauki - Arctika, natural science, 2, 5-23 [in Russian].

2 Anisimov, O.A. \& Zhil'cova, E.L. (2012). Ob otsenkakh izmenenii klimata rehionov Rossii v XX i nachale XXI vekov po dannym nabliudenii [On estimates of climate change in the regions of Russia in the 20th and early 21 st centuries according to observations]. Meteorolohiia i hidrolohiia - Meteorology and hydrology, 6, 95-107 [in Russian].

3 Gruza, G.V., Rankova, E.Y., \& Aristova, L.N. (2006). O neopredelennosti nekotorykh stsenarnykh klimaticheskikh prohnozov temperatury vozdukha i osadkov na territorii Rossii [On the uncertainty of some scenario climate forecasts of air temperature and precipitation in Russia]. Meteorolohiia i hidrolohiia - Meteorology and hydrology, 10, 5-23 [in Russian].

4 Zhiltsova, E.L., \& Anisimov, O.A. (2009). O tochnosti vosproizvedeniia temperatury i osadkov na territorii Rossii hlobalnymi klimaticheskimi arkhivami [On accuracy of reproduction of temperature and precipitation in Russia by global climate archives]. Meteorolohiia i hidrolohiia - Meteorology and hydrology, 10, 79-90 [in Russian].

5 Isachenko, A.G. (2003). Vvedenie v ekolohicheskuiu heohrafiu [Introduction into ecological geography]. Saint Petersburg: Saint-Petersburg University Publ. [in Russian].

6 Jabbari, A., So, J.-M. \& Bae, D.-H. (2020). Precipitation forecast contribution assessment in the coupled meteo-hydrological models. Atmosphere, 11(1), 34. https://doi.org/10.3390/atmos 11010034

7 Kokorev, V.A., \& Anisimov, O.A. (2013). Postroenie optimizirovannoi ansamblevoi klimaticheskoi proektsii dlia otsenki posledstvii izmenenii klimata na territorii Rossii [Building an optimized ensemble climate projection to assess the effects of climate change in Russia]. Problemy ekolohicheskoho modelirovaniia i monitorinha ekosistem - Problems of ecological modeling and monitoring of ecosystems, 25, 131-153 [in Russian].

8 Harris, I., Jones, P.D., \& Osborn, T.J. (2014). Updated high-resolution grids of monthly climatic observations - the CRU TS3.10 Dataset. International Journal of Climatology, 34(3), 623-642.

9 Kuzmina, Zh.V., \& Treshkin, S.E. (2004). Klimaticheskie izmeneniia v basseine Nizhnei Volhi i ikh vliianie na sostoianie ekosistem [Climate changes in the Lower Volga basin and their impact on ecosystems]. Aridnye ekosistemy - Arid ecosystems, 20, 3(60), 14-32 [in Russian].

10 Kouzmina, J.V. (2004). The impact of natural and human-induced changes in the river flow and the climate on flood plain ecosystems in the middle Elbe river basin. Ecological Engineering and Environment protection, 2, 5-15.

11 Akpambetova, K.M. \& Abieva, G.B. (2019). Heohraficheskie faktory razmeshcheniia rechnykh dolin na territorii Tsentralnoho Kazakhstana [Geographical factors of river valleys in Central Kazakhstan]. Evraziiskii soiuz uchenykh - Eurasian Unity of Scientists, 4(61), 26-31 [in Russian]. 
12 Dmitriev, E.A. (1995). Matematicheskaia statistika v pochvovedenii [Mathematical statistics in soil science]. Moscow: Moscow State University Publ. [in Russian].

13 Saraf, V.R., \& Regulwar, D.G. (2016). Assessment of climate change for precipitation and temperature using statistical doqnscaling methods in upper Godavari river basin, India. Journal of Water Resource and Protection, 8, $34-45$. https://doi.org/10.4236jwrp.2016.81004

14 Ghebrezgabher, M.G. (2016). Long-term trend of climate change and drought assessment in the horn of Africa. Advances in Meteorology, Article ID 8057641 https://doi.org/10.1155/2016/8057641 